\title{
NEW IN VITRO MODEL TO EVALUATE KINETICS OF ANTIMYCOBACTERIAL DRUG RELEASE FROM BIORESORBABLE POLYMERIC CARRIERS
}

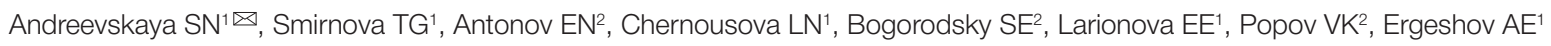

' Central Tuberculosis Research Institute, Moscow, Russia

2 Institute of Photon Technologies FSRC 'Crystallography and Photonics' RAS, Moscow, Russia

Sustained-release drugs against tuberculosis are a promising approach to therapy since they positively affect patient compliance with long regimens, especially when it comes to the multidrug-resistant form of the disease. Conventional UV-visible spectroscopy does not work well with multicomponential culture media used for growing M. tuberculosis. The aim of this study was to develop a method for evaluating the kinetics of anti-tuberculosis drug released from bioresorbable polymeric carriers suitable for screening a wide range of encapsulated prolonged-release drugs and identifying the best performing candidate. While studying the growth dynamics of the laboratory susceptible strain $M$. tuberculosis $\mathrm{H} 37 \mathrm{Rv}$ in the presence of different levofloxacin concentrations (from 0.03 to $0.4 \mu \mathrm{g} / \mathrm{ml}$ ), we developed a model, which is essentially a set of 2 parallel experiments evaluating the kinetics of drug release into the culture medium. The results of these 2 experiments conducted on 3 encapsulated forms of levofloxacin loaded onto bioresorbable polymeric PLGA carriers (particles sized $50 \mu \mathrm{m}$ and $100 \mu \mathrm{m}$ and the matrix) revealed that release kinetics of the drug largely depended on the type of polymeric carrier. The best encapsulation of the antibiotic and its gradual release into the culture medium was observed for the matrix. All experiments were run in 3 replicates. The obtained data were analyzed using descriptive statistics.

Keywords: Mycobacterium tuberculosis, in vitro model, levofloxacin, bioresorbable polymeric carrier, sustained-release

Funding: the study was supported by the Russian Ministry of Science and Higher Education and carried out as part of the State Assignment for FSRC "Crystallography and Photonics" RAS (developing an SCF-based method for creating bioactive matrices), as part of the State Assignment № 0515-2019-0015 (Formation of resistance to antimycobacterial drugs in mycobacteria and somatic cells) for the Central Tuberculosis Research Institute (evaluation of the bacteriostatic activity of different levofloxacin concentrations). The study was also supported by the Russian Foundation for Basic Research (Project № 18-29-06062 mk: development of sustained-release therapeutic formulations and an in vitro model for the evaluation of their efficacy).

Author contribution: Andreevskaya SN — interpretation of study results, manuscript preparation; Smirnova TG — modeling of conditions for levofloxacin release from its carriers; discussion of study results; Antonov EN — preparation of matrices; discussion of study results; Chernousova LN, Ergeshov AE — study design; discussion of study results; Bogorodsky SE — preparation of microparticles; discussion of study results; Larionova EE — literature analysis; discussion of study results; Popov VK — method for antibiotic encapsulation into polymeric carriers; discussion of study results.

Compliance with ethical standards: manipulations with virulent strains of $M$. tuberculosis were conducted in compliance with the safety guidelines for the experiments involving Risk Group III-IV pathogens, infectious agents and utilization of medical waste specified in sanitary regulations 1.3.2322-08, 1.3.2518-09, 1.3.2885-11, and 2.1.7.2790-10

$\measuredangle$ Correspondence should be addressed: Sofia N. Andreevskaya Yauzskaya alleya, 2, str. 1A., Moscow, 107564; andsofia@mail.ru Received: 06.08.2020 Accepted: 20.08.2020 Published online: 30.08.2020 DOI: $10.24075 /$ brsmu.2020.050

\section{НОВАЯ МОДЕЛЬ IN VITRО ДЛЯ ОЦЕНКИ ВЫСВОБОЖДЕНИЯ ПРОТИВОТУБЕРКУЛЕЗНЫХ ПРЕПАРАТОВ ИЗ БИОРЕЗОРБИРУЕМЫХ ПОЛИМЕРНЫХ НОСИТЕЛЕЙ}

С. Н. Андреевская ${ }^{\circledR}$, Т. Г. Смирнова'

${ }^{1}$ Центральный научно-исследовательский институт туберкулеза, Москва, Россия

2 Институт фотонных технологий Федерального научно-исследовательского центра «Кристаллография и фотоника", Москва, Россия

Создание противотуберкулезных препаратов пролонгированного действия крайне перспективно, так как позволяет сохранить приверженность больных к лечению при длительных курсах терапии, особенно при химиотерапии туберкулеза с множественной лекарственной устойчивостью. Традиционно используемый для оценки кинетики выхода препаратов из полимерных носителей метод УФ-спектрофотометрии не подходит для применения в многокомпонентных питательных средах для культивирования микобактерий туберкулеза. Целью исследования было разработать метод оценки высвобождения противотуберкулезных препаратов из биорезорбируемых полимерных носителей, позволяющий проводить скрининг большого числа инкапсулированных пролонгированных форм противотуберкулезных препаратов и отбирать наиболее перспективные композиции. При изучении динамики роста лабораторного чувствительного штамма M. tuberculosis H37Rv в присутствии серии концентраций левофлоксацина (от 0,03 до 0,4 мкг/мл) была разработана модель, представляющая собой два параллельно проводимых опыта, позволяющих оценить кинетику высвобождения препарата в культуральную среду. Все эксперименты проводили трехкратно, при оценке использовали методы описательной статистики. Результаты, полученные В этой модели для трех инкапсулированных форм левослоксацина в биорезорбируемых полимерных носителях из полилактогликолида (частицы 50 и 100 мкм и матрикс), показали, что кинетика накопления препарата в среде существенно зависит от вида полимерного носителя. Наиболее перспективен из них матрикс, который хорошо включает в себя левофлоксацин и достаточно равномерно высвобождает его при инкубации в питательной среде. Ключевые слова: микобактерии туберкулеза, модель in vitro, левофлоксацин, биорезорбируемые полимерные носители, пролонгированное высвобождение Финансирование: работа выполнена при поддержке Министерства науки и высшего образования в рамках выполнения работ по Государственному заданию ФНИЦ «Кристаллография и фотоника» РАН в части развития СКФ методов формирования биоактивных матричных структур, в рамках выполнения работ по Государственному заданию ФГБНУ «ЦНИИТ» № 0515-2019-0015 «Формирование лекарственной устойчивости микобактерий и соматических клеток к противотуберкулезным препаратам» В части оценки бактериостатической активности диапазона концентраций левофлоксацина и РФФИ (проект № 18-29-06062 мк) в части разработки лекарственных форм пролонгированного действия и in vitro модели оценки их эффективности.

Вклад авторов: С. Н. Андреевская - интерпретация результатов, написание текста рукописи; Т. Г. Смирнова - отработка условий для оценки высвобождения левофлоксацина из носителя, обсуждение результатов; Е. Н. Антонов - формирование матриксов, обсуждение результатов; Л. Н. Черноусова, А. Э. Эргешов - разработка дизайна исследования, обсуждение результатов; С. Э. Богородский - формирование микрочастиц, обсуждение результатов; Е. Е. Ларионова - анализ литературы, обсуждение результатов; В. К. Попов - разработка метода включения антибиотика в полимеры, обсуждение результатов.

Соблюдение этических стандартов: работы с вирулентными штаммами M. tuberculosis проводили с соблюдением мер безопасности при работе с патогенами III-IV группы патогенности согласно требованиям СП 1.3.2322-08 (с дополнениями СП 1.3.2518-09 и СП 1.3.2885-11) «Безопасность работы с микроорганизмами III-IV групп патогенности (опасности) и возбудителями паразитарных болезней», СанПиН 2.1.7.2790-10 «Санитарноэпидемиологические требования к обращению с медицинскими отходами".

$\triangle$ Для корреспонденции: Софья Николаевна Андреевская Яузская аллея, д. 2, стр. 1А, г. Москва, 107564; andsofia@mail.ru Статья получена: 06.08.2020 Статья принята к печати: 20.08.2020 Опубликована онлайн: 30.08.2020 DOI: $10.24075 /$ vrgmu.2020.050 
Over the past decade, the global incidence of multidrugresistant tuberculosis (MDR-TB) has been on the rise [1]. Difficult, lengthy treatment regimens often discourage patients with MDR-TB, undermining their compliance with therapy. A promising solution to this problem would be sustainedrelease anti-TB drugs (ATBD) encapsulated in bioresorbable polymer microparticles ensuring targeted delivery and controlled release of the active ingredient from the polymeric carrier into surrounding tissues over a prolonged period of 1-4 weeks [2]. The use of supercritical fluid technologies (SCF) can create versatile environmentally friendly micronized systems completely free from organic solvent residues [3]. The release time of the drug from the polymer carrier depends on the properties of the polymer matrix (microcapsule): its composition, dispersion and morphology. In some cases, the active ingredient is concentrated on or immediately below the surface of the carrier, which results in a rapid uncontrolled release of the encapsulated drug. This initial burst release poses a serious problem for the application of polymeric carriers since it can have a toxic effect on the body [4-6].

UV-visible spectroscopy is employed to estimate the kinetics of drug release from polymer microparticles or matrices. This technique can measure drug accumulation in a phosphate buffered saline incubated with a polymeric drug carrier [4] However, given that many microorganisms and specifically Mycobacterium tuberculosis (MTB) are fastidious and require enriched, complex culture media to support their growth [7], which impedes spectral analysis, UV-visible spectroscopy produces only rough estimates and cannot be used to evaluate drug release kinetics under near-natural conditions.

The aim of this study was to design an in vitro model for the evaluation of ATBD release kinetics from polymeric carriers in a culture medium suitable for MTB growth.

\section{METHODS}

Levofloxacin (LFX), a compulsory component of MDR-TB treatment regimens, was chosen for encapsulation into the bioresorbable carrier.

The plan was to adapt our experimental model for work in an automated BACTEC MGIT 960 system. Advantageously, BACTEC MGIT 960 can be used to work with highly effective standardized and ISO9001-certified reagents and conventional protocols [8]. In BACTEC MGIT 960, culture is performed in special mycobacteria growth indicator tubes (MGIT). At the bottom of the tube, there is a bound fluorophore under a semipermeable membrane. Fluorophore release and emission of light of a certain wavelength are directly proportional to oxygen consumption by bacterial cells in the tube: the more vigorously dividing cells there are, the more oxygen they consume, causing brighter fluorescence. Time to culture growth in the presence of a tested drug is an important parameter allowing to infer the antimycobacterial effect or the lack of thereof. Significant (over 3 days) growth delay of $M$. tuberculosis cultured in the presence vs. absence of an antimycobacterial drug means partial death of the mycobacterial population induced by the tested drug.

\section{Encapsulated LFX formulations}

Bioresorbable carriers for LFX (Sigma-Aldrich; USA) were fabricated from Purasorb PDLG7502 poly(lactic-co-glycolic acid) (PLGA, inherent viscosity: $0.2 \mathrm{dl} / \mathrm{g}$; by CorbionPurac, Netherlands). High-purity oxygen dioxide (99.998\%; NiiKm; Russia) was used without additional purification. PLGA was combined with LFX (10\% wt., i.e. $100 \mathrm{mg}$ of LFX per each $900 \mathrm{mg}$ of the polymer), compressed in cylindrical molds, plasticized with supercritical $\mathrm{CO}_{2}$ and foamed while lowering the actual $\mathrm{CO}_{2}$ pressure to the atmospheric pressure. The obtained matrices were chilled with dry ice and cryoground in a rotor mill to generate microparticles with an average size of 50 and $100 \mu \mathrm{m}$; details are provided in [4].

The precalculated amount of the polymeric microparticles with encapsulated LFX was incubated in a Middlebrook $7 \mathrm{H} 9$ broth at $37^{\circ} \mathrm{C}$ for 66 days; samples of the broth containing LFX released from the carriers were collected at predefined time points.

\section{MTB culture}

The tests were conducted on the susceptible laboratory strain M. tuberculosis H37Rv from the collection of the Central Research Institute of Tuberculosis. For our experiments, we used suspensions of well-separated $M$. tuberculosis cells harvested in the log phase for which CFU were counted. To prepare the suspension, the culture grown in a LowensteinJensen medium was passaged at $37^{\circ} \mathrm{C}$ in a Dubos broth (Difco; USA) supplemented with $0.5 \%$ BSA for two cycles of 14 days each. Then, $20 \mu \mathrm{l}$ drops of 10 -fold serial dilutions of the suspension filtered through a $5 \mu \mathrm{m}$ pore size filter (Millipore; USA) were transferred to Petri dishes coated with Dubos agar (Difco; USA). The dishes were cultured at $37^{\circ} \mathrm{C}$; the initial suspension was stored at $4{ }^{\circ} \mathrm{C}$. After $3-4$ days, mycobacterial colonies were counted under an inverted microscope (Olympus; USA) operated at $\times 200$ magnification. The suspension of mycobacterial cells $(500 \mu \mathrm{l})$ standardized to CFU was seeded into MGIT tubes containing a Middlebrook 7H9 broth (BD; USA) supplemented with OADC. Automated detection of mycobacterial growth was performed in BACTEC MGIT 960 (BD; USA).

\section{Evaluation of bacteriostatic activity by BACTEC MGIT 960}

The bacteriostatic activity of the tested formulation was evaluated based on the presence of mycobacterial growth in a MGIT tube containing the drug. Earlier experiments in a BACTEC MGIT 960 system conducted on MTB cultures with varying CFU numbers had revealed that a reduction in CFU by less than $75 \%$ (75\% growth inhibition) caused at least a 3-day delay in mycobacterial growth; a reduction by at least $90 \%$ caused an 8-day delay; by $99 \%$, a 16 -day delay; by $99.9 \%$, a 21-day delay, etc. [9]. The experiment described in this paper was conducted according to the manufacturer's protocol and lasted for 42 days. All grown colonies were subject to species identification. Acid-fastness was tested by means of ZiehlNeelsen staining. If a positive MGIT tube contained acid-fast bacteria, a rapid immunochromatography assay (BD MGIT TBC Identification test) was performed following the manufacturer's instructions. To monitor the presence of nonspecific bacteria in the BACTEC MGIT 960 system, the bacterial suspension was cultured in blood agar. Microbial growth registered after $24 \mathrm{~h}$ of incubation at $37{ }^{\circ} \mathrm{C}$ indicated nonspecific bacterial contamination of the studied sample.

\section{Statistical analysis}

The obtained data were analyzed using descriptive statistics. All microbiological experiments were conducted in 3 replicates. Statistical analysis was carried out in Microsoft Office Excel 2019 (Microsoft; USA). 
Table 1. Growth dynamics of M. tuberculosis H37Rv in the presence of levofloxacin

\begin{tabular}{|c|c|c|c|}
\hline LFX concentration, $\mu \mathrm{g} / \mathrm{ml}$ & Growth onset (days), Mean $\pm \mathrm{SD}$ & Growth delay relative to control, days & Growth inhibition, $\%$ \\
\hline 0 (drug-free control) & $6.07 \pm 0.06$ & - & - \\
\hline 0.03125 & $6.08 \pm 0.12$ & no & - \\
\hline 0.0625 & $6.20 \pm 0.27$ & no & 25 \\
\hline 0.125 & $7.69 \pm 0.09$ & 1.62 & 90 \\
\hline 0.15 & $16.92 \pm 1.14$ & 18.69 & 99 \\
\hline 0.20 & $24.76 \pm 3.21$ & 100 \\
\hline 0.25 & \multicolumn{2}{|c|}{ there is no growth of culture } & 100 \\
\hline 0.3 & \multicolumn{2}{|c|}{ there is no growth of culture } & 100 \\
\hline 0.4 & \multicolumn{2}{|c|}{ there is no growth of culture } \\
\hline
\end{tabular}

\section{RESULTS}

Since our plan was to estimate the accumulation of the drug in a culture medium based on the dynamics of MTB growth in a BACTEC MGIT960 system, we decided not to place the polymeric carrier directly into the MGIT tube for a number of reasons. First, the polymer could have impacted fluorophore fluorescence and skewed the results of the experiment. Second, with such experimental design, we would have been able to estimate only final concentrations of the tested formulation after complete drug release, but not its concentrations within the first few hours or days of incubation.

Therefore, the polymeric carrier loaded with the drug was added into a Middlebrook $7 \mathrm{H} 9$ broth (the same culture medium as in MGIT tubes). Samples of the broth $(100 \mu l)$ containing the released antibiotic were collected at equal time intervals. The amount of encapsulated LFX taken for incubation in Middlebrook $7 \mathrm{H} 9$ was precalculated to ensure that once the antibiotic was completely released from the carrier, its concentration in $100 \mu \mathrm{l}$ of the culture medium equaled its minimal inhibitory concentration (MIC) in an MGIT tube after the addition of the same volume of culture medium into the tube.

LFX loaded into the polymeric carrier can be distributed on its surface or throughout the entire carrier volume. So, we assumed that the superficially localized drug would be easy to remove from the carrier by vigorous washing. The polymeric carrier was washed in Middlebrook 7H9 multiple times. Briefly, the polymeric carrier placed into a centrifuge test tube was immersed in 30 $\mathrm{ml}$ of a sterile culture medium, vortex shaken and centrifuged

Table 2. Growth inhibition of $M$. tuberculosis H37Rv exposed to LFX released from a polymeric carrier

\begin{tabular}{|c|c|c|c|c|c|c|c|c|c|c|c|c|}
\hline \multirow{3}{*}{$\begin{array}{l}\text { Incubation } \\
\text { time }\end{array}$} & \multicolumn{6}{|c|}{ Growth inhibition, \%* } & \multicolumn{6}{|c|}{ LFX concentration in the medium ${ }^{\star *}, \mu \mathrm{g} / \mathrm{ml}$ (amount released, \%) } \\
\hline & \multicolumn{2}{|c|}{ Particles sized $50 \mu \mathrm{m}$} & \multicolumn{2}{|c|}{ Particles sized $100 \mu \mathrm{m}$} & \multicolumn{2}{|c|}{ Matrix } & \multicolumn{2}{|c|}{ Particles sized $50 \mu \mathrm{m}$} & \multicolumn{2}{|c|}{ Particles sized $100 \mu \mathrm{m}$} & \multicolumn{2}{|c|}{ Matrix } \\
\hline & unwashed & washed & unwashed & washed & unwashed & washed & unwashed & washed & unwashed & washed & unwashed & washed \\
\hline $1 \mathrm{~h}$ & 90 & 0 & 90 & 0 & 0 & 0 & $0.15(60)$ & - & $0.15(60)$ & - & - & - \\
\hline $3 \mathrm{~h}$ & 90 & 0 & 99 & 0 & 0 & 0 & $0.15(60)$ & - & $0.20(80)$ & - & - & - \\
\hline 1 days & 99 & 0 & 99 & 0 & 0 & 25 & $0.20(80)$ & - & $0.20(80)$ & - & - & $0.125(25)$ \\
\hline 3 days & 99 & 0 & 99 & 0 & 0 & 25 & $0.20(80)$ & - & $0.20(80)$ & - & - & $0.125(25)$ \\
\hline 7 days & 99 & 0 & 99 & 0 & 0 & 90 & $0.20(80)$ & - & $0.20(80)$ & - & - & $0.15(30)$ \\
\hline 10 days & 99.9 & 50 & 99 & 0 & 0 & 90 & $0.225(90)$ & $0.135\left(67.5^{\star \star \star}\right)$ & $0.20(80)$ & - & - & $0.15(30)$ \\
\hline 16 days & 99.9 & 50 & 99 & 0 & 0 & 99 & $0.225(90)$ & $0.135(67.5)$ & $0.20(80)$ & - & - & $0.2(40)$ \\
\hline 22 days & 99.9 & 50 & 99 & 0 & 0 & 99 & $0.225(90)$ & $0.135(67.5)$ & $0.20(80)$ & - & - & $0.2(40)$ \\
\hline 29 days & 99.99 & 75 & 99.99 & 25 & 25 & 99.9 & $0.235(94)$ & $0.145(72.5)$ & $0.235(94)$ & $0.09(90)$ & $0.125(50)$ & $0.225(45)$ \\
\hline 45 days & 99.99 & 75 & 99.99 & 25 & 90 & 100 & $0.235(94)$ & $0.145(72.5)$ & $0.235(94)$ & $0.09(90)$ & $0.15(60)$ & $0.25(50)$ \\
\hline 66 days & 99.99 & 75 & 99.99 & 25 & 99 & 100 & 0.235 (94) & $0.145(72.5)$ & $0.235(94)$ & $0.09(90)$ & $0.2(80)$ & $0.25(>50)$ \\
\hline
\end{tabular}

Note: ${ }^{*}$ — calculated based on the growth delay relative to the control drug-free culture; ${ }^{* \star}$ — determined from the dose-response curve (see Figure); ${ }^{\star * \star}$ — hereinafter (in the experiments involving matrix washing): accounts for the drug amount washed from the carrier surface (\% of the washed formulation = \% of the unwashed drug released into the medium within $3 \mathrm{~h}$ ); unwashed — indicates the experiment without carrier washing, washed - indicates the experiment involving carrier washing; - the amount of released LFX is not enough to achieve the desired bacteriostatic effect $(<0.125 \mu \mathrm{g} / \mathrm{ml})$.

at 3,000 $\mathrm{g}$ for $5 \mathrm{~min}$ at room temperature; the supernatant was removed. The washed carrier was ready for further experiments. Considering that the antibiotic could be localized to the surface of the carrier, the amount of the tested drug was doubled in the experiments involving the washed carrier (vs. the unwashed carrier) to ensure the probability of a bacteriostatic effect in cases when some of the antibiotic had been eliminated from the surface of the carrier. In the experiment involving the unwashed carrier, $6.3 \mathrm{mg}$ of the polymer loaded with LFX $(0.63 \mathrm{mg})$ was incubated in $30 \mathrm{ml}$ of the culture medium. For the experiment involving the washed carrier, $12.6 \mathrm{mg}$ of the carrier loaded with LFX (1.26 mg) was incubated in $30 \mathrm{ml}$ of the culture medium.

Thus, the proposed model is essentially a set of 2 experiments run in parallel evaluating LFX release into the culture medium from washed and unwashed polymeric carriers. Drug release kinetics can be elucidated by comparing the results of the 2 experiments. For example, if a rapid bacteriostatic effect is observed in the medium incubated with the unwashed encapsulated LFX formulation but no bacteriostatic effect is observed in the aliquots of the medium incubated with the washed formulation, it means that the drug (or most of the drug) is distributed on the surface of its polymeric carrier. A delayed bacteriostatic effect observed for the washed vs. unwashed encapsulated LFX formulation would suggest that some amount of the drug was evenly distributed throughout the polymer carrier during synthesis, while some amount of it remained on the surface of the carrier. If the unwashed LFX formulation has a delayed bacteriostatic effect on MTB in comparison with the unwashed formulation, the drug is evenly distributed in the polymeric carrier 


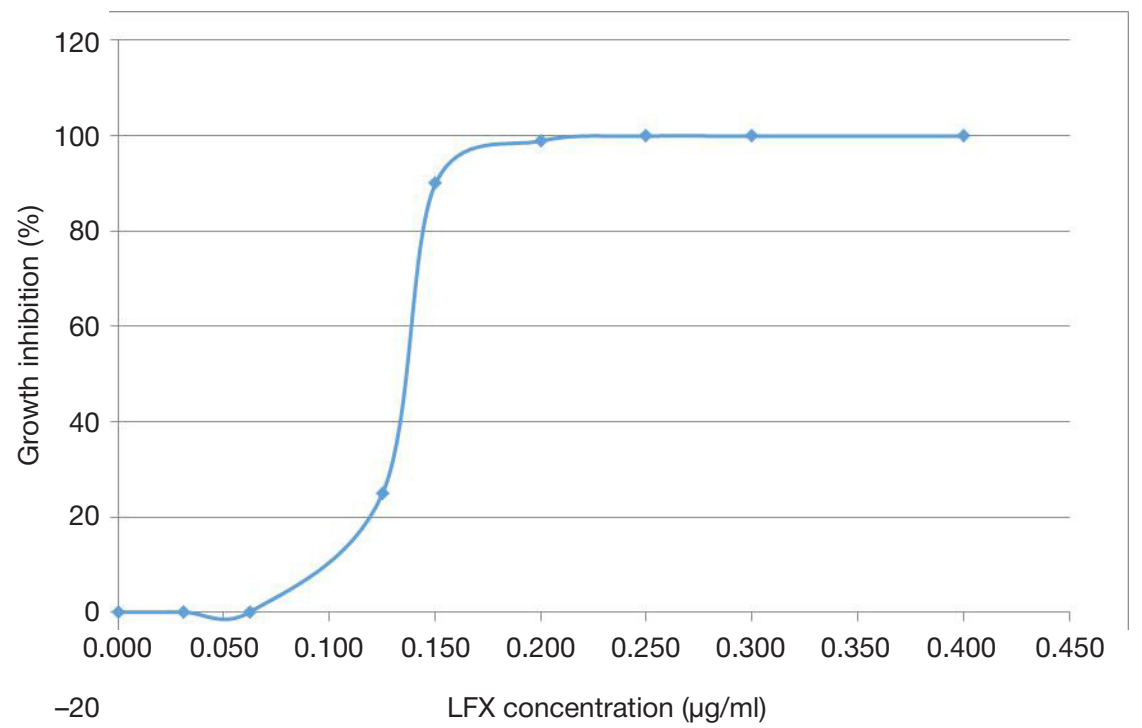

Figure. An LFX dose-response curve for the susceptible H37Rv strain of M. tuberculosis

and released gradually (bear in mind that the amount of the washed LFX formulation was doubled in comparison with the unwashed, so the bacteriostatic effect was faster).

\section{Effects of different LFX concentrations on the growth dynamics of $M$. tuberculosis H37Rv}

To determine the amount of encapsulated LFX formulation necessary for exploring the kinetics of drug release into a culture medium, we studied the effects of different LFX concentrations on the growth of an MTB laboratory strain. Briefly, after CFU were counted, the mycobacterial culture was incubated with LFX taken at a range of different concentrations from 0.031 to $0.4 \mu \mathrm{g} / \mathrm{ml}$ in a BACTEC MGIT 960 system. A drug-free MTB culture was used as a control (Table 1). For the strain used in our experiment, LFX MIC was $0.25 \mu \mathrm{g} / \mathrm{ml}$. Based on the obtained data, we constructed a dose-response curve (Figure) subsequently used to determine the amount of LFX released from the polymeric carrier into the culture medium.

\section{Evaluation of kinetics of LFX release from bioresorbable polymers into culture medium based on growth dynamics of M. tuberculosis H37Rv}

Following the procedures described above, we studied 3 encapsulated LFX formulations differing in the carrier type: a PLGA matrix and particles sized $50 \mu \mathrm{m}$ and $100 \mu \mathrm{m}$. A drugfree MTB culture and a MTB culture containing samples of the medium incubated with the intact PLGA matrix (without LFX) were used as controls. The results are provided in Table 2.

An immediate bacteriostatic effect was observed for PLGA particles sized 50 and $100 \mu \mathrm{m}$ in the experiments involving the unwashed formulation; the bacteriostatic effect was delayed in the experiment involving the washed polymeric carrier. This suggests that at least $60 \%$ of the antibiotic was concentrated on the polymer surface: after $3 \mathrm{~h}$ of incubation, the unwashed carrier released $0.15-0.20 \mu \mathrm{g} / \mathrm{ml}$ of LFX into the culture medium, which was enough to inhibit the growth of $90 \%$ of the mycobacterial population.

By contrast, LFX encapsulated into the PLGA matrix had a delayed bacteriostatic effect on the mycobacterial population in the experiment without carrier washing (with carrier washing on day 1 and without carrier washing on day 29); this suggests that LFX was evenly distributed throughout the matrix and was released gradually. Besides, the experiment with the washed matrix shows that some amount of the drug was concentrated just below the surface: $25 \%$ of LFX was released on day 1 , causing inhibition of $25 \%$ of mycobacterial cells; then the drug was gradually released until $50 \%$ of it was present in the medium on day 45; complete inhibition of mycobacterial growth was observed for LFX concentrations of $0.25 \mu \mathrm{g} / \mathrm{ml}$ (MIC).

No differences were observed between the growth of cultures with added aliquots of the medium incubated with the drug-free matrix and the growth of untreated cultures, indicating adequacy of the proposed model.

\section{DISCUSSION}

The proposed model and the experiments described in this study can be used to evaluate the release kinetics of anti-TB agents in a culture medium in vitro based on the inhibition of $M$. tuberculosis growth. Previous in vitro studies of antimycobacterial activity looked at the kinetics of liposomal formulations that were not meant for gradual drug release but merely facilitated delivery of the tested drug to the target. Those experiments relied on a classic in vitro design and aimed at evaluating the efficacy of encapsulated formulations vs. pure active substance and assessing the immediate toxic effect of the liposome on mycobacterial cells [10-12]. In vitro models were also exploited to study sustained-release drugs against bacteria other than members of the Mycobacterium genus, such as Staphylococcus aureus; they involved constructing time-response curves for cultures grown in the presence of a polymer carrier with an encapsulated antibiotic [13].

The antimicrobial effect of encapsulated anti-TB drugs was mainly studied in in vivo models. Experiments on mice and rabbits demonstrated high anti-TB activity, prolonged effect and reduced toxicity (as compared to traditional therapeutic formulations) for PLGA-based microparticles loaded with rifampin [14], isoniazid [15, 16], ethionamide [17], rifampin + isoniazid [18], and rifampin + cycloserine [19]. Using experimental animals for testing long-acting encapsulated formulations makes the laboratory part and data analysis much easier, because in this way the pharmacokinetics of the drug can be studied under natural conditions. On the other hand, in vivo models are costly and, for ethical reasons, cannot be employed for screening studies involving a wide range of carriers and active ingredients. Developing a model for evaluating the growth of $M$. tuberculosis at different time points in the presence of the drug released into the medium is a promising approach since such a 
model would allow testing more than one combination of carriers and encapsulated drugs and identifying the best-performing candidate for future in vivo experiments.

The analysis of the obtained data offers an answer to the question of whether the drug- loaded carrier should be prepared for the experiment (washed before the experiment to remove the active substance localized to its surface) and allows determining the amount of the drug needed for the in vivo experiment, given the preparatory washing and the release kinetics.

\section{CONCLUSION}

The proposed in vitro model allows conducting screening studies of encapsulated, sustained-release formulations of
anti-TB drugs. This approach helps to select the most promising formulation with smaller amounts of the drug concentrated on the carrier surface and ensuring its gradual release through the experiment.

Tests of 3 different formulations of LFX encapsulated in bioresorbable PLGA carriers revealed that release kinetics of the tested drug largely depended on the type of polymeric carrier. The best encapsulation of the antibiotic and its gradual release into the medium was observed for the matrix.

The proposed model can be used in screening studies investigating the antimycobacterial activity of encapsulated LFX or other encapsulated drugs. Such screening conducted before an in vivo experiment will reduce its costs and offer a solution to some ethical issues.

\section{References}

1. World Health Organization. Global tuberculosis report 2019. Geneva: World Health Organization, 2019.

2. Bogorodskii SE, Krotova LI, Mironov AV, Popov VK. Fabrication of highly porous bioresorbable polymer matrices Using Supercritical Carbon Dioxide. Russian Journal of Physical Chemistry B. 2013; 7 (8): 916-23.

3. Alsenz J, Kansy M. High troughput solubility measurement in drug discovery and development Adv Drug Del Rev. 2007; 59: 546.

4. Antonov EN, Bogorodskiy SE, Dunayev AG, Krotova LI, Mariyanats AO, Syachina MA, i dr. Razrabotka komponentov antibakterial'nykh lekarstvennykh form prolongirovannogo deystviya $\mathrm{S}$ ispol'zovaniyem SKF-tekhnologiy. Sverkhkriticheskiye flyuidy: teoriya i praktika. 2020; 15 (1): 124-35. Russian.

5. Yehia SA, Elshafeey AH, Elsayed I. A novel injectable in situ forming poly-DL-lactide and DL-lactide/glycolide implant containing lipospheres for controlled drug delivery. J Liposome Res. 2012; 22 (2): 128-38.

6. Ahmed T. Review: approaches to develop PLGA based in situ gelling system with low initial burst. Pak J Pharm Sci. 2015; 28 (2): 657-65.

7. Ergeshov AE, editor. Tuberkulez organov dykhaniya. Rukovodstvo dlya vrachey. M.: Galleya-Print, 2017; 524 s. Russian.

8. Chernousova LN, Sevastyanova EV, Larionova EE, Smirnova TG, Andreyevskaya SN, i dr. Federal'nyye klinicheskiye rekomendatsii po organizatsii i provedeniyu mikrobiologicheskoy i molekulyarnogeneticheskoy diagnostiki tuberkuleza. Tver': Triada, 2014; 29 s.

9. Matyugina E, Khandazhinskaya A, Chernousova L, Andreevskaya S, Smirnova T, Chizhov A, et al. The synthesis and antituberculosis activity of 50-nor carbocyclic uracil derivatives. Bioorganic and Medicinal Chemistry. 2012; 20: 6680-86.

10. Bhardwaj A, Kumar L, Narang RK, Murthy RS. Development and characterization of ligand-appended liposomes for multiple drug therapy for pulmonary tuberculosis. Artif Cells Nanomed Biotechnol. 2013; 41 (1): 52-9.

11. Sorokoumova GM, Yasin YaOH, Mikulovich YuL, Smirnova TG, Andreyevskaya SN, Selishcheva AA, i dr. Sozdaniye i

\section{Литература}

1. World Health Organization. Global tuberculosis report 2019. Geneva: World Health Organization, 2019.

2. Bogorodskii SE, Krotova LI, Mironov AV, Popov VK. Fabrication of highly porous bioresorbable polymer matrices Using Supercritical Carbon Dioxide. Russian Journal of Physical Chemistry B. 2013; 7 (8): 916-23.

3. Alsenz J, Kansy M. High troughput solubility measurement in drug discovery and development Adv Drug Del Rev. 2007; 59: 546.

4. Антонов Е. Н., Богородский С. Э., Дунаев А. Г., Кротова Л. И., Мариянац А. О., Сячина М. А., и др. Разработка компонентов антибактериальных лекарственных форм

izucheniye svoystv liposomal'noy formy levofloksatsina. Tonkiye khimicheskiye tekhnologii. 2013; 8 (5): 72-6. Russian.

12. Andreevskaya SN, Smirnova TG, Zhogina YA, Smirnova DI, Mikulovich YL, Sorokoumova GM, et al. Effect of exogenous cardiolipin on the growth and viability of Mycobacterium tuberculosis H37Rv in vitro. Dokl Biol Sci. 2010; 434: 371-4.

13. Qiao Z, Yuan Z, Zhang W, Wei D, Hu N. Preparation, in vitro release and antibacterial activity evaluation of rifampicin and moxifloxacin-loaded poly( $(\mathrm{D}, \mathrm{L}$-lactide-co-glycolide) microspheres. Artif Cells Nanomed Biotechnol. 2019; 47 (1): 790-8.

14. Quenelle DC, Staas JK, Winchester GA, Barrow EL, Barrow WW. Efficacy of microencapsulated rifampin in Mycobacterium tuberculosis-infected mice. Antimicrob Agents Chemother. 1999; 43 (5): 1144-51.

15. Kailasam S, Daneluzzi D, Gangadharam PR. Maintenance of therapeutically active levels of isoniazid for prolonged periods in rabbits after a single implant of biodegradable polymer. Tuber Lung Dis. 1994; 75 (5): 361-5.

16. Gangadharam PR, Kailasam S, Srinivasan S, Wise DL. Experimental chemotherapy of tuberculosis using single dose treatment with isoniazid in biodegradable polymers. J Antimicrob Chemother. 1994; 33 (2): 265-71.

17. Kumar G, Malhotra S, Shafiq N, Pandhi P, Khuller GK, Sharma S. In vitro physicochemical characterization and short term in vivo tolerability study of ethionamide loaded PLGA nanoparticles: potentially effective agent for multidrug resistant tuberculosis. $J$ Microencapsul. 2011; 28 (8): 717-28.

18. Dutt M, Khuller GK. Therapeutic efficacy of Poly(DL-lactideCo-Glycolide)-encapsulated antitubercular drugs against Mycobacterium tuberculosis infection induced in mice. Antimicrob Agents Chemother. 2001; 45 (1): 363-6.

19. Naydenova AA, Sukoyan GV, Vorontsov EA, Kuznetsov SL, Gukasova NV, Ryabtseva MS, i dr. Razrabotka nanosomal'nykh kompozitsiy rifampitsina i D-tsikloserina na osnove polilaktidglikolidov i issledovaniye ikh protivotuberkuleznoy aktivnosti. Nanotekhnologii i okhrana zdorov'ya. 2012; 3 (12): 23-30. Russian.

пролонгированного действия с использованием СКФтехнологий. Сверхкритические флюиды: теория и практика. 2020; 15 (1): 124-35.

5. Yehia SA, Elshafeey AH, Elsayed I. A novel injectable in situ forming poly-DL-lactide and DL-lactide/glycolide implant containing lipospheres for controlled drug delivery. J Liposome Res. 2012; 22 (2): 128-38.

6. Ahmed T. Review: approaches to develop PLGA based in situ gelling system with low initial burst. Pak J Pharm Sci. 2015; 28 (2): 657-65.

7. Эргешов А. Э., редактор. Туберкулез органов дыхания. 
Руководство для врачей. М.: Галлея-Принт, 2017; 524 с.

8. Черноусова Л. Н., Севастьянова Э. В., Ларионова Е. Е., Смирнова Т. Г., Андреевская С. Н., Попов С. А. и др. Федеральные клинические рекомендации по организации и проведению микробиологической и молекулярно-генетической диагностики туберкулеза. Тверь: Триада, 2014; 29 с.

9. Matyugina E, Khandazhinskaya A, Chernousova L, Andreevskaya S, Smirnova T, Chizhov A, et al. The synthesis and antituberculosis activity of 50-nor carbocyclic uracil derivatives. Bioorganic and Medicinal Chemistry. 2012; 20: 6680-86.

10. Bhardwaj A, Kumar L, Narang RK, Murthy RS. Development and characterization of ligand-appended liposomes for multiple drug therapy for pulmonary tuberculosis. Artif Cells Nanomed Biotechnol. 2013; 41 (1): 52-9.

11. Сорокоумова Г. М., Ясин Я. О. Х., Микулович Ю. Л., Смирнова Т. Г., Андреевская С. Н., Селищева А. А., и др. Создание и изучение свойств липосомальной формы левофлоксацина. Тонкие химические технологии. 2013; 8 (5): 72-6.

12. Andreevskaya SN, Smirnova TG, Zhogina YA, Smirnova DI, Mikulovich YL, Sorokoumova GM, et al. Effect of exogenous cardiolipin on the growth and viability of Mycobacterium tuberculosis H37Rv in vitro. Dokl Biol Sci. 2010; 434: 371-4.

13. Qiao Z, Yuan Z, Zhang W, Wei D, Hu N. Preparation, in vitro release and antibacterial activity evaluation of rifampicin and moxifloxacin-loaded poly(D,L-lactide-co-glycolide) microspheres. Artif Cells Nanomed Biotechnol. 2019; 47 (1): 790-8.
14. Quenelle DC, Staas JK, Winchester GA, Barrow EL, Barrow WW. Efficacy of microencapsulated rifampin in Mycobacterium tuberculosis-infected mice. Antimicrob Agents Chemother. 1999; 43 (5): 1144-51.

15. Kailasam S, Daneluzzi D, Gangadharam PR. Maintenance of therapeutically active levels of isoniazid for prolonged periods in rabbits after a single implant of biodegradable polymer. Tuber Lung Dis. 1994; 75 (5): 361-5.

16. Gangadharam PR, Kailasam S, Srinivasan S, Wise DL. Experimental chemotherapy of tuberculosis using single dose treatment with isoniazid in biodegradable polymers. J Antimicrob Chemother. 1994; 33 (2): 265-71.

17. Kumar G, Malhotra S, Shafiq N, Pandhi P, Khuller GK, Sharma S. In vitro physicochemical characterization and short term in vivo tolerability study of ethionamide loaded PLGA nanoparticles: potentially effective agent for multidrug resistant tuberculosis. $J$ Microencapsul. 2011; 28 (8): 717-28.

18. Dutt M, Khuller GK. Therapeutic efficacy of Poly(DL-lactideCo-Glycolide)-encapsulated antitubercular drugs against Mycobacterium tuberculosis infection induced in mice. Antimicrob Agents Chemother. 2001; 45 (1): 363-6.

19. Найденова А. А., Сукоян Г. В., Воронцов Е. А., Кузнецов С. Л., Гукасова Н.В., Рябцева М. С. и др. Разработка наносомальных композиций рифампицина и D-циклосерина на основе полилактидгликолидов и исследование их противотуберкулезной активности. Нанотехнологии и охрана здоровья. 2012; 3 (12): 23-30. 